\title{
UDC 539.53:620.17
}

\section{DETERMINATION OF MECHANICAL PROPERTIES OF STEEL 15Kh2NMFA USING INSTRUMENTED INDENTATION RESULTS}

\author{
Oleg Katok; Ievgen Kondryakov; Roman Kravchuk; Valeriy Kharchenko
}

\author{
G. S. Pisarenko Institute for Problems of Strength, Kyiv, Ukraine
}

\begin{abstract}
Summary. The algorithm of reproduction of the deformation curve for the tensile test specimens using the contact deformation diagram parameters has been devised. The mechanical characteristics of steel 15Kh2NMFA have been determined from the uniaxial tension diagram obtained by the instrumented indentation method. It is illustrated that the deflection between the strength characteristics determined from the indentation and tensile test results does not exceed $1 \%$.
\end{abstract}

Key words: instrumented indentation method, tensile test, indentation diagram, finite element method.

Received 24.02.2018

Introduction. Providing the reliable operation and possibilities to prolong the responsible equipment lifetime greatly depend on the correctness and the accuracy of determination of the mechanical properties of the structural materials and their change while operating. Nowadays there is a great need to obtain new data on the reactor vessel materials and other important nuclear plants equipment deformation and fracture processes, taking into account the real loading conditions, determination of their damage while operating.

In order to obtain more complete and precise information on the material behavior under loading, the instrumented methods of the materials and the structural elements testing are being developed efficiently in the world, which are based on the compilational recording of the parameters of the total process of deformation. Among such methods the instrumented indentation method, known as the method of the kinetic hardness, is one of the most important [1-3]. Now this method is developed efficiently and widely used for the determination of the structural materials degradation, but raising of the determination accuracy of the metal mechanical properties, as well as it was earlier, is of great importance and a pressing task for the fracture mechanics [4-5].

To raise the reliability of the current control of the mechanical properties of the equipment elements structural materials basing on the indentation methods it is worth while taking advantage of the approach for the reproduction of the metal tension diagram according to the parameters of the contact deformation diagram [6-7].

The objective of the work is to obtain the diagram of the uniaxial tension of the steel 15Kh2NMFA taking advantage of the instrumented indentation method and further to determine the mechanical properties of the material.

The approach for the reproduction of the tensile test specimens deformation diagram according to the instrumented indentation results.

This approach is based on the solving of the forward and inverse problems of the software complex modeling of the material continuous contact deformation process by the indenter basing on the finite elements method.

The development of the finite element model, computational modeling of the material contact deformation process by the indenter and plotting of the instrumented indentation diagram while processing the obtained results are the components of solution of the forward problem. While solving the forward problem the tensile diagram is known in advance. The 
forward problem approvement is performed on the model material, for which the diagrams of the specimens tensile deformation and indentation are determined. The problem is considered to be solved, if the deflection of the instrumented indentation diagrams, plotted according to the results of the experimental tests and those of the computation modeling, does not exceed $1 \%$.

While solving the reverse problem the experimental indentation diagram is the data mass for the computational modeling. The solving of the problem itself is the reproduction of the tensile diagram using the calculation model plotted while solving the forward problem. The algorithm of reproduction of the deformation diagram of the specimens tensile test using the instrumented indentation is shown in Fig. 1

The problem is solved as follows. The mechanical properties of the material are determined using the experimental indentation diagram, according to which the initial metal tensile diagram is plotted. The obtained diagram is used for the computational modeling of the instrumented indentation process. According to the results of the computational modeling the diagram of the contact deformation is plotted, which is compared with the experimental one. If the deflection between the diagrams of the instrumented indentation built according to the results of the experimental data and those of computational modeling does not exceed $1 \%$, the initial diagram of the metal tension is considered to be reliable. In another case, the initial diagram of the metal tension must be adjusted and the computational modeling must be performed using the adjusted diagram.

Plotting of the diagram for the VVER-1000 reactor vessel metal deformation according to the results of the computational modeling of the indentation process.

The solution of the forward problem and the detailed description of the finite element model for the calculation of the material contact deformation by the steel ball is presented in the paper [8]. The structural steel 45 was used as the model material.

The reverse problem was solved for the steel 15Kh2NMFA. To determine the current values of the mechanical properties of the steel 15Kh2NMFA being widely applied for the production of the corresponding nuclear plants equipment (bodies, caps and other units of the reactors), the methods and corresponding to them equipment developed at the G. S. Pisarenko Institute for Problems of strength of the NAS of Ukraine, have been used [9-11].

The values of the mechanical properties, obtained taking advantage to the instrumented indentation method, are presented below: ultimate strength being $\sigma_{\mathrm{B}}=748,0 \mathrm{MPa}$, yield strength $-\sigma_{0,2}=611,0 \mathrm{MPa}$ and modulus of elasticity $-E=1,92 \times 10^{5} \mathrm{MPa}$.

The initial diagram of the specimens tensile deformation is plotted according to the values of the mechanical properties determined due to the indentation results. To plot such a diagram the special software has been developed, which makes possible not only to plot the tensile diagram due to the mechanical properties determined taking advantage of the instrumented indentation method, but to perform and adjust it depending on the deflection value between the diagrams the instrumented indentation being plotted according to the results of the experimental data and computational modeling.

The initial diagram of the specimens tensile deformation is presented in Fig. 2, where the comparison of the instrumented indentation diagrams is shown, which were plotted according to the experimental data and the computational modeling. Is is seen, that the values of the maximum loading on the indenter under the computational modeling being lower than the real value. Deflection between the diagrams in the loading area is $4,5 \%$, in the unloading area $-3 \%$. 


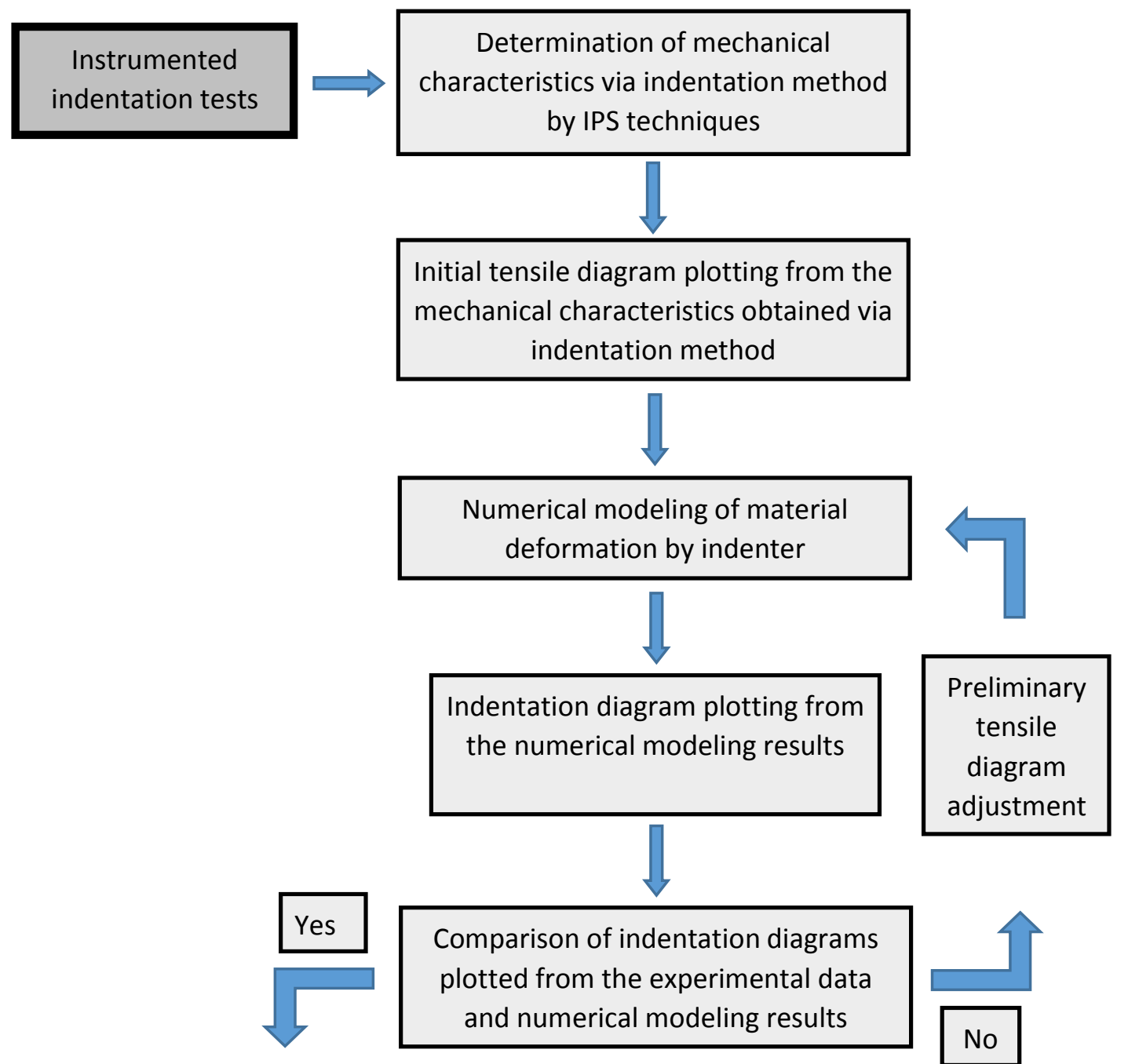

Tensile diagram used in the modeling is the valid tensile diagram for the tested material

Determination of mechanical material characteristics by the tensile diagram

Figure 1. Algorithm of reproduction of the deformation curve for the tensile test specimens using the instrumented indentation results
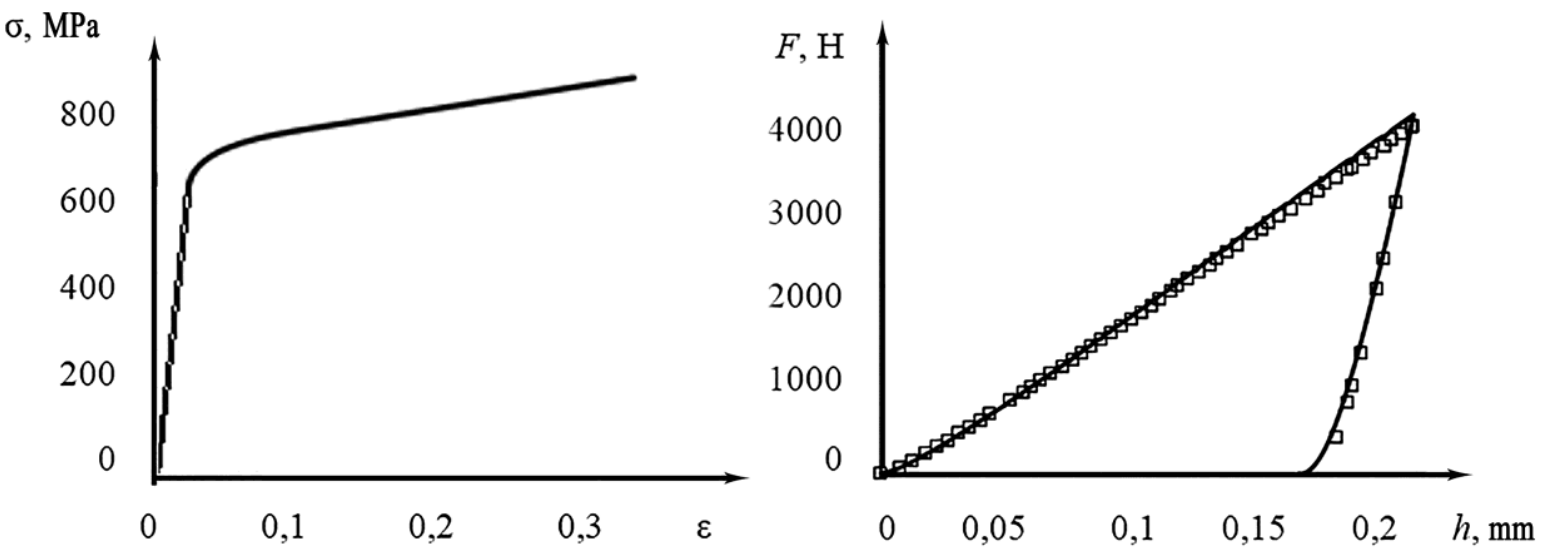

Figure 2. Initial diagram of the deformation of the tensile test specimens (a) and comparison of the instrumented indentation diagrams (b) developed from the experimental data (solid line) and numerical simulation ( $\square$ ) 
Because of the sufficient deflection between the calculated and experimental data the adjustment of the initial tensile diagram was performed taking into account the differences between the indentation diagrams built according to the results of the experimental data and those of the computational modeling.

The adjustment of the deformation diagram for the tensile test specimens had been performed up till the deflection between the indentation diagram, did not exceed 1\%. In Fig. 3 the indentation diagrams for the steel 15Kh2NMFA within the coordinates "loading $\mathrm{F}$ indentation depth $h$ " are presented, which were plotted according to the results of the experimental data and the computational modeling using the adjusted tension diagram at the final iteration.
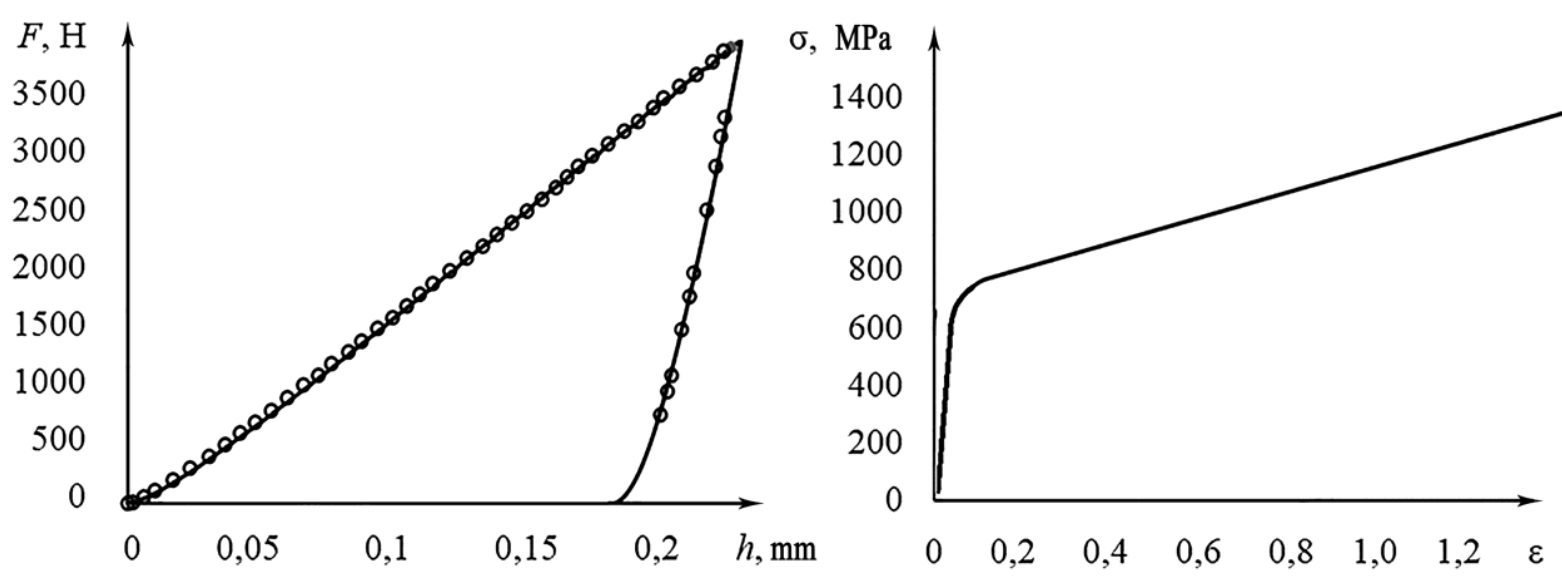

Figure 3. Diagrams of the contact steel ball deformation of 15Kh2NMFA in coordinates load $\mathrm{F}$ vs indentation depth $\mathrm{h}$ (a) based on the experimental data (solid line) and numerical modeling ( $\mathrm{O}$ ) using the adjusted tension diagram at the final iteration (b)

The uniaxial tension diagram for the reactor vessel metal (steel 15Kh2NMFA), obtained using the computational modeling of the indentation process, is presented in Fig. 3,b. The values of the mechanical properties characteristic, determined due to the uniaxial tension diagram obtained taking advantage of the instrumented indentation method and specimens tensile tests according to the ГОСТ 1497-84 standards, are presented on the Table 1.

Table 1

Comparison of the mechanical properties of steel 15Kh2NMFA determined using different methods

\begin{tabular}{|l|c|c|c|}
\hline \multirow{2}{*}{ Mechanical properties } & \multicolumn{2}{|c|}{ Values, MPa } & \multirow{2}{*}{$\begin{array}{c}\text { Deflection } \\
\Delta, \%\end{array}$} \\
\cline { 2 - 3 } & ГOCT $1497-84$ & Indentation method & 0,4 \\
\hline Yield strength, $\sigma_{0,2}$ & 640,5 & 638,1 & 0,6 \\
\hline Ultimate strength, $\sigma_{\mathrm{B}}$ & 724,2 & 728,4 & 0 \\
\hline
\end{tabular}

Conclusions. Taking advantage of the developed methods and updated experimental equipment for the structural materials testing, using the method of instrumented indentation, the approach of the reproduction of the deformation diagram for the tensile test specimens according to the results of such testings, has been proposed, the uniaxial tension diagram of the steel $15 \mathrm{Kh} 2 \mathrm{NMFA}$ being obtained experimentally. Owing to it the deflection between the 
values of the strength characteristics determined while indentation and tensile testings does not exceed $1 \%$.

\section{Refferences}

1. Metallic materials - Instrumented indentation test for hardness and materials parameters. ISO 14577 1:2002, ISO 14577-3:2002.

2. Matyunin V.M. Operativnaya diagnostika mexanicheskix svojstv konstrukcionnyx materialov. Moskow: Izdatel'skij dom ME'I, 2006, pp. 214. [In Russian]

3. Bakirov M.B., Potapov V.V., Frolov I.V. Razrabotka raschetno-e'ksperimental'nyx metodik polucheniya mexanicheskix xarakteristik na osnove metoda kineticheskogo indentirovaniya. Mir izmerenij, 2006, no. 8 , pp. 5 - 11. [In Russian].

4. Alexin V.P., Bulychev S.I., Kalmakova A.V. et al. Kineticheskoe indentirovanie $\mathrm{v}$ probe nerazrushayushhego kontrolya i diagnostiki materialov. Zavod. lab., 2004, vol. 70, no.6, pp. 46 - 51. [In Russian].

5. Katok O.A., Rudnitskii N.P., Kharchenko V.V., Bazhukov A.V., Ialnik P.A. On the Determination of the Mechanical Characteristics of Steels from Hardness Test Results. Strength Mater, 2014, vol. 46, no. 6, pp $773-776$.

6. Dao M., Chollacoop N., Van Vliet K. J. et al. Computational modeling of the forward and reverse problems in instrumented sharp indentation. Acta Materialia, 2001, vol. 49, pp. 3899 - 3918.

7. Bakirov M.B., Mishulina O.A., Kiselev I.A. et al. Issledovanie vozmozhnosti vosstanovleniya diagramm deformirovaniya s pomoshh'yu nejrosetevogo podxoda. Zavod. lab, 2010, vol. 76, no. 7, pp. 42 - 48. [In Russian.]

8. Katok O.A., Lenzion S.V., Kharchenko V.V. Chislennoe modelirovanie processa nepreryvnogo indentirovaniya. Nadezhnost' i dolgovechnost' mashin i sooruzhenij, 2007, vol. 29, pp. 167 - 173. [In Russian].

9. Kharchenko V.V., Katok O.A., Drozdov O.V. et al. Perenosnyi prylad dlia vyznachennia kharakterystyk mitsnosti metaliv metodom instrumentovanoho identuvannia. Nadezhnost y dolhovechnost mashyn y sooruzhenyi, 2009, vol. 32, pp. 162 - 168. [In Ukrainian].

10. Kharchenko V.V., Rudnickij N.P., Katok O.A. et al. Ustanovka dlya opredeleniya mexanicheskix xarakteristik konstrukcionnyx materialov metodom instrumentirovannogo indentirovaniya. Nadezhnost' i dolgovechnost' mashin i sooruzhenij, 2007, vol. 28, pp. 140 - 147. [In Russian].

11. Katok O.A., Kharchenko V.V., Drozdov A.V., Panasenko A.V. Opredelenie mexanicheskix svojstv stalej metodom nepreryvnogo indentirovaniya. Nadezhnost' i dolgovechnost' mashin i sooruzhenij, 2008, vol. 31, pp. 208 - 213. [In Russian].

\section{Список використаної літератури}

1. Матюнин, В.М. Оперативная диагностика механических свойств конструкционных материалов [Текст] / В.М. Матюнин - М: Издательский дом МЭИ, 2006. -214 с.

2. Бакиров, М.Б. Разработка расчетно-экспериментальных методик получения механических характеристик на основе метода кинетического индентирования [Текст] / М.Б. Бакиров, В.В. Потапов, И.В. Фролов // Мир измерений. - 2006. - № 8. - С. 5 - 11.

3. Кинетическое индентирование в пробе неразрушающего контроля и диагностики материалов [Текст] / В.П. Алехин, С.И. Булычев, А.В. Калмакова [и др.] // Завод. лаб. - 2004. - Том 70. - № 6. C. $46-51$.

4. Katok, O.A. On the Determination of the Mechanical Characteristics of Steels from Hardness Test Results [Text] / O.A. Katok, N.P. Rudnitskii, V.V. Kharchenko, A.V. Bazhukov, P.A. Ialnik // Strength Mater., 2014, vol. 46, no. 6, pp $773-776$.

5. Dao, M. Computational modeling of the forward and reverse problems in instrumented sharp indentation [Text] / M. Dao, N. Chollacoop, K.J. Van Vliet [et ell] // Acta Materialia. - 2001. - 49. - P. 3899 - 3918.

6. Исследование возможности восстановления диаграмм деформирования с помощью нейросетевого подхода [Текст] / М.Б. Бакиров, О.А. Мишулина, И.А. Киселев [и др.] // Завод. лаб. - 2010. Том 76. - № 7. - С. $42-48$.

7. Каток, О.А. Численное моделирование процесса непрерывного индентирования [Текст] / О.А. Каток, С.В. Лензион, В.В. Харченко // Надежность и долговечность машин и сооружений. 2007. - Вып. 29. - С. 167 - 173. 
8. Переносний прилад для визначення характеристик міцності металів методом інструментованого ідентування [Текст] / В.В. Харченко, О.А. Каток, О.В. Дроздов [та ін.] // Надежность и долговечность машин и сооружений. - 2009. - Вып. 32. - С. 162 - 168.

9. Установка для определения механических характеристик конструкционных материалов методом инструментированного индентирования [Текст] / В.В. Харченко, Н.П. Рудницкий, О.А. Каток [и др.] // Надежность и долговечность машин и сооружений. - 2007. - Вып. 28. - С. 140 - 147.

10. Каток, О.А. Определение механических свойств сталей методом непрерывного индентирования [Текст] / О.А. Каток, В.В. Харченко, А.В. Дроздов, А.В. Панасенко // Надежность и долговечность машин и сооружений. - 2008. - Вып. 31. - С. 208 - 213.

\title{
УДК 539.53:620.17
}

\section{ВИЗНАЧЕННЯ МЕХАНІЧНИХ ХАРАКТЕРИСТИК СТАЛІ 15Х2НМФА ЗА РЕЗУЛЬТАТАМИ ІНСТРУМЕНТОВАНОГО ІНДЕНТУВАННЯ}

\section{Олег Каток; Свген Кондряков; Роман Кравчук; Валерій Харченко}

\author{
Інститут проблем мічності ім. Г.С. Писаренка НАН Украӥни, \\ Київ, Украӥна
}

\begin{abstract}
Резюме. Розроблено алгоритм відтворення діаграми деформування зразків на розтяг за параметрами діаграми контактного деформування. Визначено механічні характеристики сталі


Показано, що відхилення між значеннями характеристик міџності, визначеними при індентуванні й випробуванні на розтяг, не перевищує $1 \%$.

Ключові слова: метод інструментованого індентування, випробування на розтяг, діаграма індентування, метод скінченних елементів.
\end{abstract}

Отримано 24.02.2018 